\title{
EUROPEAN POLICY ON PORT ENVIRONMENTAL PROTECTION
}

AI. M. GOULIELMOS

Received: 26/08/99

Accepted: 27/09/00

\author{
University of Piraeus \\ Department of Maritime Studies \\ 40, Karaoli \& Dimitriou St. \\ GR - 185 32, Piraeus, Greece
}

e-mail: ag@unipi.gr

\section{ABSTRACT}

Ports are part of the logistics chain and the transport networks, with a decisive role in the protection of the sea environment. In the present work, the environmental protection of ports is defined as a problem in the transport sector and within the marine environment. Port pollution and its causes are briefly presented. The concepts of sustainability and sustainable mobility are discussed and it is argued that the environmental protection issues should be introduced into the production function of ports. Next, policy issues are considered and the conflicts of objectives between the two E.U. main directorates (Transport and Environment) are pointed out. Finally, policy recommendations are given.

KEY WORDS: Port environmental protection, Port environmental policies, European Union environmental policies.

\section{INTRODUCTION}

European Environmental Policies were discussed for the first time at the Paris European Summit Meeting, (Kula, 1992). The $5^{\text {th }}$ Environmental Action Program (1987-1992) set as priority the Water Pollution, and its sub-areas such as maritime pollution and coastal zones protection. The first concern on the European Union (E.U.) agenda was the protection of the Atlantic Ocean (1981), North Sea (1984) and later Mediterranean Sea. Unfortunately, the environmental protection of ports was left aside for later consideration.

Transport has been the target sector for environmental concern as early as 1973 , but received the appropriate attention only after 1989 (Commission of European Communities, 1990). However, ports were not considered as part of the logistics chain of transport or as part of the transport network that connects sea and land. Although landbased pollutant emissions and the coastal degra- dation did deserve an action (European Transport Coastal Charter).

Unlike environmental policies, marine pollution has received much attention by International Maritime Organisation (IMO) (ESCAP, 1992), United Nations Conference on Trade And Development (UNCTAD, 1993), United Nations (1994, 1996), Comité Maritime International (CMI), International Navigation Association (PIANC), World Bank (Davis et al., 1990) and others. IMO, in particular, dealt with transport, handling and storage of dangerous substances in ports. In Agenda 21, (United Nations, 1994), ports' activities are considered as one of the sectors affecting coastal areas and where reception facilities for the collection of oily and chemical residuals and garbage should be established. Additionally, workshops on environmental aspects of port operation and development had to be carried out. 
Specific E.U. policy for the port's environment does not exist. Port activities are considered part of the transport and, especially, part of the multimodal trans-European networks and from this point of view they should be considered as falling into the objectives of sustainable mobility (Commission of European Communities, 1997).

Environmental policies related to ports should pay attention to the "environmental sensitive areas", which had been put into effect under the article 19 of Council Regulation 797/85. Related to this concept is the Convention on wetlands of international importance, (e.g. Wildfowl Habitat, 1971), RAMSAR (Convention on Wetlands of International importance especially as waterfowls habitats) sites and bird habitats protected under the EC directive 79/409, which has created the "Special Protection Areas". EC directive 94/43 on the Conservation of natural Habitats and Wild Fauna and Flora (1991) is also important in that respect.

The problem with any port expansion or development is the priority between environmental and social-economic issues (Finney and Young, 1995). Apart from tight development rights, a totally different management approach is needed on special protection areas. Projects in those areas are permitted on the basis of overriding public interest (social or economic). Following E.C. Council directive 92/43/EEC, this is implemented by Natura 2000 Network of EC Commission. Terminal expansion of ports should then be examined whether they are detrimental to a Special Area of Conversation (SAC) site (19992004). The European Court case No 57/89, European Commission versus Federal Republic of Germany (FRG) (28/2/91) is relevant to this issue. In UK, if environmental benefits are prevented from inadequate port facilities (e.g. transferring freight from road to coastwise shipping), government should provide a grant, shippers transferring cargos by the sea may be subsidized or restitution of the area may be possible (UK Royal Commission, 1994).

Ports are not only parts of the transport network but are also located on the coast or on riverbanks. Transport, together with energy-generation plant and industry are considered as the major sources of carbon dioxide emissions. Short sea shipping, although short in length (in comparison to road traffic), entails traffic increase and possible con- gestion on seaports. A $1 \%$ modal shift from road freight transport to shipping would allow a reduction of $\mathrm{CO}_{2}$ emissions by $0,2 \%$ (EC, 1998). The Kyoto Protocol (articles 2.2 and 3.2) concludes that the creation of an integrated logistics management system with full use of telematics would allow a $\mathrm{CO}_{2}$ reduction of about $4 \%$.

\section{BACKGROUND OF THE PROBLEM}

Modern ports - especially those of the third generation - have emerged as parts of the logistics chain, (Goulielmos, 1998). The passive role of ports against whatever was coming from sea towards the mainland and from mainland towards the sea has changed (Pronk, 1993), but their strategic location between sea and land makes them the best witnesses of pollution coming from land, ships and from the ports themselves.

Attention on port's environment has not been paid to at all, as this is indicated by the limited literature dealing with this topic. The port environment is threatened by: port's hinterland, ships activity, port activity and port operation. Ports pollution may result from ship accidents, accidents in ports (Goulielmos and Pardali, 1998), land activities, ship bunkering, noises, garbage, dust, dredging, port maintenance, ship air pollution, traffic congestion, sewage and others. The attention of international community has been concentrated mainly to port's visitors, (i.e. the ships), because of the well-known marine accidents. Despite of this, the issue of material dredging from ports has been addressed as early as in 1975 (London Dumping Convention) and pollution of the sea from oil and the facilities for waste reception in ports, as early as in 1973 (MARPOL 73/78, The International Convention for the Prevention of Pollution from ships). The issue of oil pollution in emergency situations in ports has been addressed since 1990 (Convention of Oil Pollution Preparedness, Response and Cooperation).

The following diagram presents the extend of port generated pollution.

On the basis of an IAPH (International Association of Ports \& Harbors) survey, filled in by 183 ports, the crucial areas were three: (1) dangerous materials, (2) water pollution, and (3) dredging and dumping of dredged waste. The third factor is connected to port expansion or conservation. IAPH thought that the following principles 


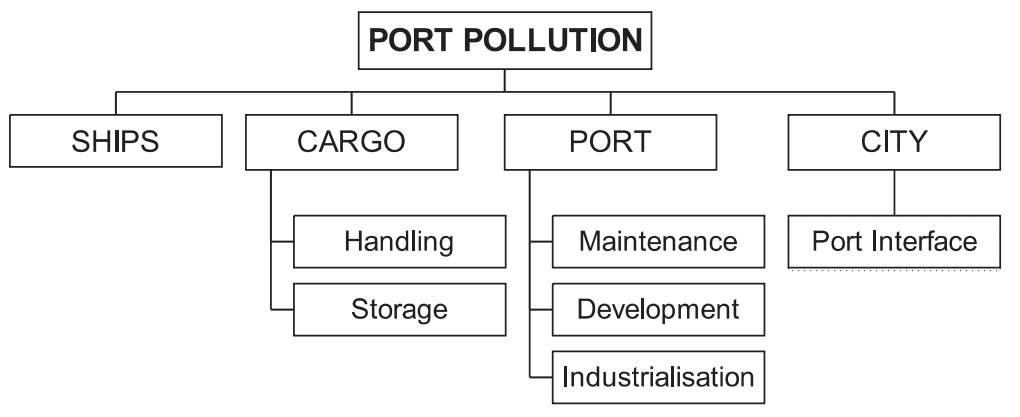

Figure 1. Port Pollution and its causes, (constructed from UNCTAD, 1993)

should apply in environmental policy making of ports:

- limit sea (from ship, land, dredging) and air pollution (dust, noise),

- use Environmental Impact Analysis (E.I.A.) in port development,

- prevent risk of major accidents (Vessel Traffic System (VTS), emergency plans, dangerous goods),

- manage waste and discharge (recovery, collection, recycling, supervised disposal areas),

- create quality areas, and

- regulate against pollution.

We will refrain from discussing MARPOL, where a lot has so far been written (Stender, 1990). What, however, may be commented is that reception facilities are generally missing in E.U. and the financial consequences of discharge into a reception facility has not been studied under a cost-benefit approach, (e.g. contamination of port's infrastructure). Bunker operations in port areas constitute, indeed, a great danger for oil pollution. However, maritime transport is responsible for only $12 \%$ of all pollution (Farthing and Brownrigg, 1997), though in terms of quantity this figure cannot be underestimated.

Handling of cargo generates dust, especially dust coming from phosphates. As argued by UNCTAD (1993), loss of product is most likely at storage and handing places, i.e. in ports with a product loss is $1 \%$ of traffic flow. The liquid products are flammable and toxic with vapour emissions. Common causes of accidents are due to rupture of connecting hoses or pipelines, bursting of valves or manifolds and failure of coupling between ship and shore. Health danger from smell and fire or explosion risks may follow. Commodities fall from cranes and are damaged by forks and forklift trucks. Damages are caused also by chemical products.

Furthermore, pollution is generated from the maintenance of port infrastructure and suprastructure works. Dominant role, here, plays the dredging and disposal of dredged material, which may also be contaminated (especially by dioxin; Gibb, 1997). In USA, the Harbour Maintenance Act (1986) imposed a tax on port use of navigable waterways (federally maintained), and the Water Resource Development Act (1996) provided for federal cost-sharing of the construction costs of the disposal facilities for dredged materials. The cost of maintenance dredging at marine terminal facilities is borne by dredging beneficiary on a permit by Environmental Protection Agency (EPA). Materials are distinguished by EPA to: (a) those that do not cause unacceptable toxicity or bio-accumulation in biological test systems, (b) those that cannot be freely disposed but failing to meet federal limiting are no threats of mortality and (c) those permissible concentration criteria for toxicity and/or bioaccumulation (heavy metals, dioxin, PCB, carcinogenic compounds). There is also the turbidity effect (UNCTAD, 1993). Possible pollution may come from maintenance of port's equipment and suprastructure due to gritblasting and spray painting or from ship repairs in the port area. If port is of a third (or even a second) generation, pollution may come from maintenance and repair works to the industrial plants located in the port.

Very important is the relationship between port development and environment, (Finney and Young, 1995; Vandermeulen, 1996; Guhnemann and Rothengatter, 1998), as traffic (demand) expands and the role of ports change from a simple hinterland terminal to a complex nodal point 
in the logistics chain. This last fact requires also change in port's infrastructure layout (UNCTAD, 1993). Apart from investment cost for dredging facilities, the infrastructure should now take into account environmental impact and environment restoration to ecological standards. Environment requirements are now part of the investment cost and this may be quite high for a port, even for those owned by the public sector (Gibb, 1997). If should be borne in mind that ecological organizations were in the past successful in canceling investment projects concerning ports (the socalled Maritime Industrial Development Areas). Environmental policies now enter drastically into the selection of new ports locations (away e.g. from river mouths). Denial of port expansion on environment reasons may favour other competing ports. Port environmental criteria should therefore be harmonized among, at least, the members-states of the E.U.

Since 1997, there is a tendency in E.U. for a modern, efficient and competitive European Port Sector, which can contribute to the principle of a sustainable mobility. The port sector integrates maritime transport and other port transport modes into the transport chain (Commission of the European Communities, 1997). Mobility is a condition for the single market, and sustainability is a condition for the protection of the European environment. Since 1992 (Commission's White Paper, 1992, Common Transport Policy), E.U. is trying to develop a more balanced transport system by promoting more environmentally friendly transport solutions like intermodality and short sea shipping (Commission of European Communities, 1995, 1996).

Although the social needs of the Community should be supported by ports, conflicts are inevitable because the concentration of cargo in a limited number of ports makes the whole situation more suitable and viable for high-volume modes like rail, except road, which may be the candidate for next use. This is a negative factor for the policy of shifting freight transport from road to sea. Smaller ships could increase their direct port calls in the future. It is thought that this attitude will permit a more balanced traffic flow and port development in E.U. Ports are to help congestion and bottleneck phenomena of the main land-corridors and minimize externalities.
Ports are also points where compliance with International and European Maritime Safety Regulations can best be checked and uniformly enforced (Directive 95/21/EC on Port State Control). IMO cargo-handling operations may be applied in a harmonized way. European Community Sea Ports Organization (ESPO, 1995) mentioned two relevant directives: (a) noise framework (1990) and (b) air framework $(84 / 360)$ linked to an integrated pollution control. The results of ships' compliance to MARPOL are disappointing and a directive will attempt to increase the availability and adequacy of reception facilities in E.U. ports. Also, there is a need of securing the use of facilities by ships, to comply with notification requirements for dangerous or polluting goods and to promote environmentally friendly oil tankers complying with the Segregated Ballast Tanks (SBT) Regulation.

European infrastructure projects can have a negative environmental impact, which is very important for the existing E.U. ports. Projects for port expansion should always be considered in the context of environmental legislation and through the appropriate E.I.A. approach. As it is pointed out, however, by Guhnermann and Rothengatter (1998) the key objectives which were set by Commission: (a) sustainable and safe mobility, (b) environment protection, (c) combination of all modes of transport (with their comparative environment advantage), (d) optimal use of existing facilities, and (e) interoperability, are too general. Performance indicators for environmental sustainability should be specified. According to European Communities (1997), all "plans and programs in sectors such as transport (including transport corridors, port facilities and airports, telecommunication and tourism)" are subjects to an E.I.A. The E.I.A. should be entitled "strategic environmental assessment" which means a formalized, systematic and comprehensive process to evaluate environmental impacts resulted by the application of a policy, a plan or a program and its alternatives. It should include the preparation of a report on the findings evaluation and should use the findings in public accountable decision-making process.

Commission recognized that ports are located close to populated areas where habitats and living species are put in danger. New port development should be considered within an integrated frame- 
work for coastal planning, taking into account the socio-economic and environmental needs and constraints of the surrounding coastal zone (com (96) 511 final OJC 129 25/4/97). A Code of Conduct (ESPO, 1995) provides a quality framework for a programmed action with respect to the protection of the environment within port areas. European Commission, following DGXI (Environment Directorate) is not keen to favour new port development given the fact that technology and operational efficiency of existing facilities may improve. Indeed, in areas with many ports, co-ordination and specialization among them should be favoured.

In safety related issues, E.U. can play an ideal role by drawing up a standard package of regulations for its ports, and ensure monitoring enforcement (Lak, 1998). A Green Award certification system, as it was suggested by Lak, should be established at European level; ships are receiving special treatment and a $6 \%$ discount on port dues. It is worth noting the argument of Couper (1992) that "port environment policies have generally been by-products of sectoral legislation" and as it is strongly argued by Heaver (1993) that "the pollution issues at sea have their consequences on ports". Van de Voorde et al. (1998) correctly believe that there is a need for research in port economics. Also, they found it striking that responsibility for part of the future controls regarding maritime safety and environment is passed on the ports by the European Commission.

Research and Development programs on Transport are directed towards the application of MARPOL rules in ports, efficient dredging and the relations between ports and their urban environment. Sustainable mobility is related to marine technology so that environmental compatibility of ports will be improved.

European Commission advances the idea that port prices should cover marginal social costs (capital, operating costs and external costs). External costs, traditionally, in economic theory relate environment, congestion and accidents. This approach will maximize economic welfare and promote economic efficiency.

Commission is prepared to favour only Projects implementing Electronic Data Interchange (EDI) and infrastructure systems covering rail, inland waterways, and short sea shipping, but for combined transport; especially, projects that link ports and have no rail links with the inland transport network, like the port of Piraeus, Greece. Port workers should be aware of environment and maritime safety through training.

\section{ANALYSIS OF PORT PRODUCTION FUNCTION}

Sustainability is a global, as well as macroeconomic term (Meadows et al., 1972, United Nations, 1972, Common, 1995), but what is important in our opinion is that it should be transformed to a microeconomic use and enter into firm's production function. A port is indeed a microeconomic unit.

Sustainable development can take various definitions (World Commission on Environment and Development, 1987): (a) as a non-declining consumption and (b) as a non-declining well being (utility) over time; utility is connected with the amount of capital (stock) and this condition may also serve intertemporal equity. Also, (c) average quality of life of our time (Hanley et al., 1997). But the ecological interpretation of sustainable development should not be forgotten (Common, 1995). The peculiar fact is that economic efficiency seems not to be a sufficient condition for sustainable development. In fact we have, today, to manage resources in such a way that the average quality of life of our time can potentially be shared by all future generations (Hanley et al., 1997).

Environment can be defined as a natural capital, synonymous to natural resources- renewable and quasi renewable- and resources or natural assets producing ecological services (Pearce and Atkinson, 1995). The traditional concept of capital for ports includes buildings, quay walls, equipment, superstructure and infrastructure. Environment could also be considered as input (Fisher, 1995), or as a constraint to growth, based on the principle of interconnectedness between growth and environment.

Port sustainable development can be defined as the situation in which the port is able to meet its own needs without endangering its own future (ESPO, 1995). According to the UNCTAD approach (UNCTAD, 1993), the major objectives of a port manager are: (a) efficient economic performance, (b) ecological sustainability, and (c) social equity. The problem is located on the way these objectives can be attained. 
Attention should be paid on the ports' development in connection with the: (a) exploitation of resources, (b) direction of investments, (c) orientation of technology and (d) institutional change (UNCTAD, 1993).

Existing ports, and those planned to be constructed, face miscellaneous problems. The decline of the quality of port's natural environment is one of the problems (i.e. particularly air, sea, water and land, Perman et al., 1996). This can also be seen as a natural capital which degradation is equivalent to its consumption. The value of offsetting degradation is equal to the cost of restoring it.

Port capital assets may be defined in three forms, as the man-made capital, $\mathrm{K}_{\mathrm{M}}$, the human capital (knowledge and skills), $\mathrm{K}_{\mathrm{H}}$, and natural capital (natural resources, energy, mineral assets, etc.), $\mathrm{K}_{\mathrm{N}}$. The capital assets should obey the following sustainability condition:

$$
\frac{d\left(K_{M}+K_{H}+K_{N}\right)}{d t} \geq 0
$$

that is the value of the net change in port's composite capital stock must be equal to or greater than zero (Bromley, 1995). Modifying Pearce and Atkinson's formula (1995) we may specify the net port investment as:

$$
\frac{d k}{d t}=R_{(t)}-\delta k_{(t)}
$$

where $R_{(t)}$ is the profit reserves for port investments. Depreciation should also be allowed for natural as well as for human capital. Depreciation

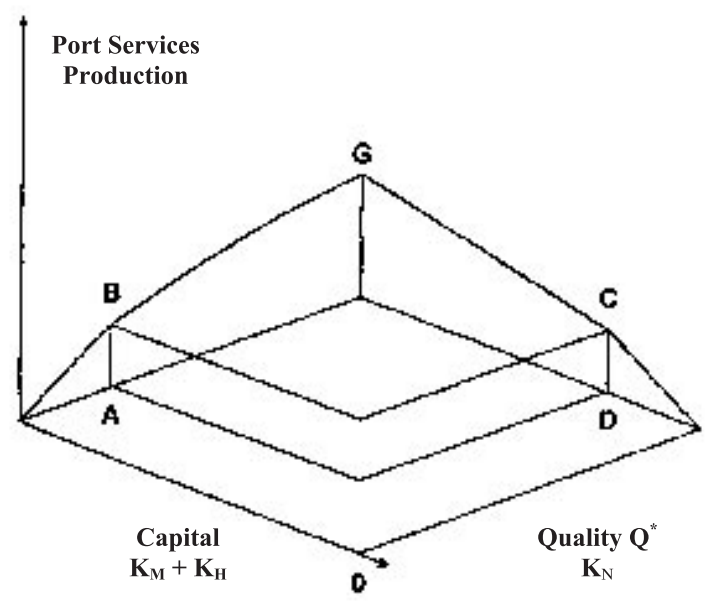

Figure 2. Port Production with natural Capital as Factor of Production of port's natural capital may include environmental degradation, which assumes the following inequality:

$$
R(t)-\delta_{M} K_{M}(t)-\delta_{H} K_{H}(t)-\delta_{N} K_{N}(t) \geq 0(3)
$$

We assume that significant depreciation of skills and knowledge during individuals' lifetime (e.g. 60 years) takes place as port technology may change at least four times (every 15 years). The above mathematical presentation of sustainability validates UNCTAD statement that a port "remaining in business and earning money is able to invest and thus support sustainable development" (UNCTAD, 1993). The possibility to substitute natural capital with man-made capital is an important issue. The assumption made, is that there is a degree of substitution between manmade capital and labour.

If port's environment cannot be freely provided in quantity and quality required, then port's production function will be as shown in Figure 2. In vertical axis production of port services is presented. The other two axes represent human and manmade capital and natural capital measured in quantity and the required quality, $\mathrm{Q}^{*}$. Production is possible with the resulting iso-quants, which are shown in Figure 3.

In such a case, capital (man-made and human) cannot substitute natural capital. Here the three factors of production should be used in fixed proportions.

As shown in Figure 3, OB natural quality capital is required to be combined with human and man made capital to provide $A_{1}$ quantity of quality port services. So, iso-quant really becomes a dot at $\mathrm{P}_{1}$. For higher production $\left(\mathrm{A}_{2}\right)$ more of both factors of production are required (OC, OD). The usual assumptions are made $\mathrm{K}_{\mathrm{M}}, \mathrm{K}_{\mathrm{H}}, \mathrm{K}_{\mathrm{N}}>0$, and iso-quants do not intersect. This production map, however, requires more natural capital for an increase in production. The marginal rate of technical substitution is unique for each isoquant. The expansion path is determined by $\mathrm{P}_{1}$, $\mathrm{P}_{2}, \mathrm{P}_{3}$, and $\mathrm{P}_{4}$ after bringing iso-cost lines and equalizing $\mathrm{P}_{\mathrm{N}}$ (price for natural capital) with natural capital depreciation. This is the amount of bringing port's environment up to the required quality and which is determined by port's management (UNCTAD, 1993, as in Port of Abidgan). 
The price for each iso-cost line $\left(\mathrm{I}_{1}\right.$ to $\mathrm{I}_{4}$ ) varies because the slope of each iso-cost line is equal to $\mathrm{P}_{\mathrm{M}+\mathrm{H}} / \mathrm{P}_{\mathrm{N}}$, although $\mathrm{P}_{\mathrm{M}+\mathrm{H}}$ and $\mathrm{P}_{\mathrm{N}}$ quantities are fixed. The tangent point must thought to be at $\mathrm{P}_{1}$ or $\mathrm{P}_{2}$ or $\mathrm{P}_{3}$ or $\mathrm{P}_{4}$, where:

$$
\text { MRTS }=\frac{\mathrm{P}_{\mathrm{M}+\mathrm{H}}}{\mathrm{P}_{\mathrm{N}}}=\frac{\mathrm{MP}_{\mathrm{M}+\mathrm{H}}}{\mathrm{MP}_{\mathrm{N}}}
$$

European Union policies focus on global environmental problems. The reduction of the "greenhouse gases" is of primary concern, and requires an immediate action. By 2010, particular attention will be given to Transport sector, where recently (1996) ports were incorporated. Transport also is considered as one of the main causes of the present urban degradation. If environment is the limit for growth and further social development of the European Union, then environmental protection should be determined as a priority, even in situations where the goal is profit maximization (including social costs) and sustainable mobility. Consistency of policies at E.U. and national level is required. Environmental protection requirements must be integrated into the definition and implementation of all E.U. policies.

Congestion at ports leads to increased energy consumption, operational pollution and loss of time and comfort. Transport demand for goods has changed, and the emphasis moved from the volume of shipped goods to the frequency and speed, reliability and flexibility, and reduced average shipment sizes. Port operations become faster, and berths are shorter.

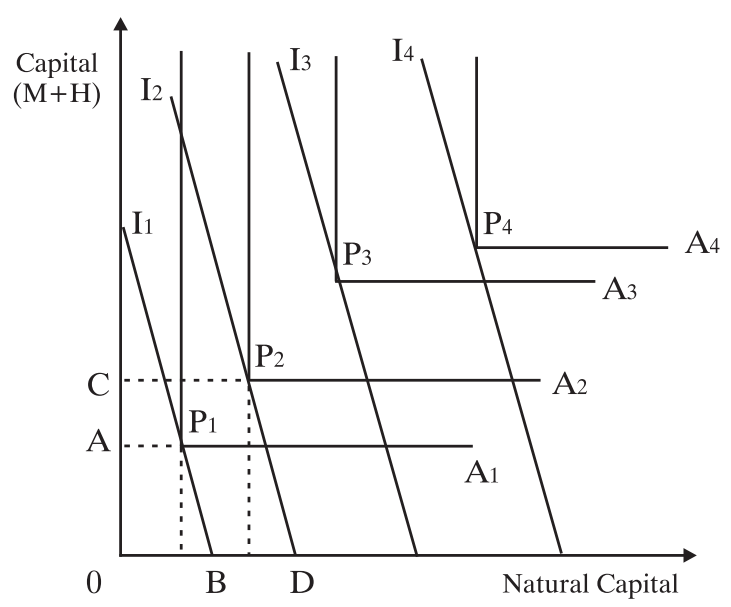

Figure 3. Points of Tangency between Port Iso-quants and Iso-cost Lines
In the long run, E.U. objective is to arrive at a less transport-intensive path of economic development mainly via the internalization of external costs of transport. Sustainability should be made a suitable tool for microeconomics. Port prices should reflect marginal social costs and at the same time maximize economic welfare and economic efficiency. External costs of marine accidents may be made partially internalized; at the present, insurance companies pay the cost of marine accidents. Pricing for marine accidents and accidents at ports should change drastically from the present practice (Goulielmos and Giziakis, 1998). Elimination of marine accidents can be attained at very high cost (Goulielmos and Giziakis, 1998).

The existence of port Sunk Costs has been found to induce ports not to choose latest (equipment) technology (Goulielmos, 1998; Sutton, 1991) perhaps this is why Commission is not happy with relationship between technology and environment. The objectives of the E.U. policy set by DGVII are:

- a safer, more efficient and environmental friendly transport system,

- a system based on interoperable national networks,

- a rise in the efficiency of each transport mode and an increase in cooperation between them,

- better planning infrastructure so that environmental damage is minimized and the quality return on investment maximized, and,

- all decision-makers (governments, transport operators, users) make the right decisions and the right choices.

However, as shown in Figure 3, port production has to use specific quantities of production factors at their (given) prices. Also, a port cannot dispose all its outlay on only man made and human capital, and labour.

If we want to achieve Pareto production efficiency, assume that there exist two port production services, A and B, (e.g. storage and loading/ unloading). The port has to allocate or reallocate all factors of production including, natural capital, between $\mathrm{A}$ and $\mathrm{B}$ by reducing production of $\mathrm{A}$ given the production of $\mathrm{B}$. This will happen when the slopes of the specific iso-quants (fig. 3) are equal on the expansion path $\left(\right.$ MRTS $_{\mathrm{M}, \mathrm{H}, \mathrm{LABOUR}}=$ $\mathrm{MRTS}_{\mathrm{N}}$ ) in the production of both services). But sustainability is not guaranteed by economic efficiency and ports, therefore, have to set pollution and accident standards. 


\section{CONCLUSIONS}

E.U. has to formulate a coherent policy on transport, port activities and environment. Concepts like efficiency and sustainability, sunk costs and technology, and port users welfare maximization, should be further searched and made more practicable for ports, including the new concept of quality of life. Ports usually serve foreign ship owners, so welfare maximization is not only through generations, but also through nations. E.U. should formulate a type of International Safety Management (ISM) Code for ports, to include issues like marine accidents and pollution standards. Port State Control should be enforced and become more effective. The amelioration of the ports' reception facilities will help in the direction of a more efficient transport sector.

\section{REFERENCES}

Bromley, D.W. (1995), The Handbook of Environmental Economics, Basil Blackwell Ltd, UK.

Commission of European Communities (1990), Group Transport 2000 plus, Transport in a fast changing Europe, $1^{\text {st }}$ Action Program on the Environment, 1973-1977.

Commission of the European Communities (1995), The development of Short Sea Shipping in Europe: Prospects and Challenges, Com. (95) 317, 5/6, Brussels.

Commission of the European Communities (1996), Shaping Europe's Maritime Future: a Contribution to the Competitiveness of Maritime Industries, Com (96) 84, 13/3, Brussels.

Commission of the European Communities, (1997), Green Paper on Sea Ports and Maritime Infrastructure, Com (97) 678 final, 10/12, Luxembourg.

Common, M. (1995), Sustainability and Policy: Limits to Economics, Cambridge University Press, UK.

Couper, A.D. (1992), Environmental Port Management, Maritime Policy and Management Journal, 9, 165-170

Davis, J.D., Macknight S., IMO Staff and Others (1990), Environmental Considerations for Port and Harbour Developments, World Bank, Technical Paper No 126, Washington, USA.

Economical Social Commission for Asia and Pacific (1992), Assessment of the Environmental Impact of Port Developments. An IMO/ESCAP seminar, Yokohama 31/8-4/9.

European Commission (1998), Communication to the Council, the European Parliament, the Economic and Social Committee and the Committee of the Regions, Communication on Transport and $\mathrm{CO}_{2}$. Developing a Community Approach, Com (98) draft, 30/3, Brussels.

European Communities (1997), Strategic Environmental Assessment of the Trans-European Transport Network, Preparatory note, Brussels.

European Sea Ports Organization (1995), Environmental Code of Practice, Brussels.

Farthing, B. and Brownrigg, M. (1997), Farthing on International Shipping, LLP, London.

Finney, N. and Young, F. (1995), Environmental zoning restrictions on port activities and development, Maritime Policy and Management Journal, 22, 319-329.

Fisher, A.C., (1995), Environmental and Resource Economics, Selected essays, Edward Elgar, Hants, UK.

Gibb, B. (1997), Dredging, environmental issues and port experience in the United States, Maritime Policy and Management Journal, 24, 313-318.

Goulielmos, A. and Pardali, A. (1998), The framework protecting ports and ships from fire and pollution, Disaster Prevention and Management, An International Journal, 7, 281-287.

Goulielmos, A.M. (1998), Continuous learning about Markets in Shipping and the impact on Ports. The Greek experience, Port Challenge 2000: The Competitive edge symposium. PMF Consultants Worldwide, 2 and 3 April, London.

Goulielmos, A.M. (1999), Deregulation in Major Greek Ports: The way it has to be done, International Journal of Transport Economics, 1999, XXVI, 121-148.

Goulielmos, A.M. and Giziakis, K. (1998), Treatment of uncompensated cost of marine accidents in a model of Welfare Economics, Disaster Prevention and Management, An International Journal, 7, 183-187.

Guhnemann, A. and Rothengatter, W. (1998), Strategic Environmental Assessment of Transport Infrastructure Investments, 8th World Conference on Transport Research, Antwerp, Belgium, 12-17 July.

Hanley, N., Shogren, J.F., and White, B. (1997), Environmental Economics in theory and Practice, MacMillan Press Ltd, London, UK.

Heaver, T.D. (1993), The many facets of Maritime Economics in association, Maritime Policy and Management Journal, 20, 121-132. 
Kula, E. (1992), Economics of Natural Resources and the Environment, Chapman and Hall, UK.

Lak, S. (1998), Ports, Focal points for Regulation, In: Quality Shipping, H. Haralambides (ed.), Erasmus Publishing, The Netherlands.

Meadows, D.H., Meadows, D.L., Randers, J. and Behrens, W.W. (1972), The Limits to Growth, Universe Books, New York.

Pearce, D. and Atkinson, G. (1995), Measuring Sustainable Development, The Handbook of Environmental Economics, Bromley D.W. (Ed.), Basil Blackwell, Oxford, UK.

Perman, R., Ma, Y. and McGilvray, J1, (1996), Natural Resource and Environmental Economics, Longman Publishing, New York, USA.

Pronk, J.P. (1993), Address to Pacem in Maribus XVIII, Ocean Yearbook, 10, Borgese et al., The University of Chicago Press, Chicago, USA.

Stender, E.G. (1990), Operational Safety and Environmental Protection in Seaports. Port Management Textbook. Vol. 1, Bremen, Germany.

Sutton, J. (1991), Sunk Costs and Market Structure, MIT Press, Boston, USA.

UK Royal Commission, (1994), Environmental Pollution, Report, HMSO, London, UK.

UNCTAD (1993), Sustainable Development for Ports, Report UNCTAD (SDD/Port) 1, 27/8, Geneva, Switzerland.

United Nations (1972) Conference on the Human Environment, Stockholm Publ. (ed), New York, USA.

United Nations, (1994), Earth Summit, Agenda 21. Program of Action from Rio, New York, USA.

United Nations, (1996), Gas emissions to be equal to those of 1990 till 2000 and to address greenhouse gases, Conference on Climate Change, New York, USA.

Van de Voorde, E., Meersman, H. and Steenssens, C. (1998), Safer and more Ecological Shipping: The impact on Port Competition, In: Quality Shipping, H. Haralambides (ed.), Erasmus University Publications, The Netherlands.

Vandermeulen, J.H. (1996), Environmental trends of ports and harbours: implications for planning and management, 23, 55-66.

World Commission on Environment and Development (1987), Our Common Future. The Brundland report, Oxford University Press, Oxford, UK. 